\title{
Ethics In A Globalized World -What Have We Wrought?!
}

Kyle B. Usrey, (E-mail: kursey@whitworth.edu), Whitworth College

\begin{abstract}
Globalization and recent corporate scandals all presage increased ethics scrutiny of personal behaviors among corporate officials. Boeing's ethics code precluding conduct that causes "embarrassment to the company" is the pacesetter.
\end{abstract}

\section{INTRODUCTION}

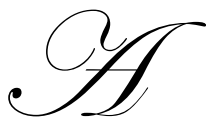

mbrose Bierce in "The Devil's Dictionary" defined a corporation as "an ingenious device for obtaining individual profit without individual responsibility." Too many people apparently subscribe to some variation of this viewpoint. A recent study indicates that MBA students are more likely to cheat than any other students; speculation is that's because they are inculcated with the business philosophy of just "get the job done" someway. (Al Lewis, The Denver Post, "Why MBA Students are Such Cheaters;" The Week October 13, 2006, p. 50) This report is shocking, and yet in many ways, it isn't. With the corporate scandals of top officials at Enron, MCI, Tyco, Hewlett-Packard, and Qwest, just to mention a few, coupled with the increased scrutiny resulting from Sarbanes-Oxley legal requirements on corporations, one would think business students at the very least would get it -that how you get it done matters, and it's not a win-at-all-costs world anymore. After all, most every business school worth its salt today has either a specific ethics course required of all its students or has ethics infused in its curriculum; a recent study shows that the number of business schools with professors devoted solely to business ethics has increased 35\% in the last two years. And this push for ethics focus has infiltrated even the boardrooms of American corporations; a Conference Board-Corpedia study published in October reported that of 225 companies surveyed, corporate board involvement in ethics programs jumped from $21 \%$ in 1987 to $96 \%$ today.

However, in contrast, two recent surveys by LRN Corp. found that unethical corporate managers (some of which presumably come from MBA programs) contribute to lower worker productivity and drive away employees and potential recruits. This follows a 2004 national poll by SHRM/CareerJournal.com that found most employees had a negative feeling about their organization's ethical leadership, with a 2002 CBS News poll finding just one in four Americans think most corporate executives are honest. Lastly, in a very recent US N\&WR/Harvard poll, business leaders rank just slightly behind state and local government leaders and slightly ahead of Congress and the Executive branch in dragging up the rear for confidence and faith in their leadership by the American public. (Silla Brush, "A Vote of No Confidence," US News \& World Report, October 30, 2006, p. 56) What explains the disconnect? Is there something we're overlooking?

Perhaps it's no coincidence that the American public cannot make much of a distinction between their politicians and business leaders - one commentator suggested that corporate chiefs are now scrutinized by the tabloids in the same way as rock stars. Maybe the reason has to do with the issue of personal hypocrisy or talk-the-talk vs. walk-the-walk ethics enforcement. (After all, Enron's last code of ethics in 2000 was 65 pages long and often held up as a paradigm of aspiring moral standards, but history showed us it was just a paper tiger.)

It used to be so easy to separate one's personal life from the professional. Of course, celebrities and national politicians have always found that a challenge, but nowadays the scope-creep of public scrutiny is closing in on all in the management world. It seems like no matter where one goes in this world, one's corporate and private transgressions, past and present, follow. As Thomas Friedman has said, we now have over 6.2 billion neighbors as a result of globalization - and they can all discover our sins at the click of a computer mouse. 
Thus, in reaction to the public's lack of trust and the prospect of the world leering at our private and professional lives, we have seen some recent, striking examples of 'no tolerance' for shenanigans off the job. Former Rep. Mark Foley's fall from grace due to charges of pedophilia in Congress just before the November 2006 elections and the sordid revelations of sexual/drug improprieties by National Association of Evangelicals President Ted Haggard about the same time were two very prescient incidences of personal hypocrisy, highlighted by the media for career-ending, shaming behaviors.

It's too easy to blame the media or a moral breakdown in our society for this phenomenon. Yet, as we bemoan this lack of privacy, perhaps we might find this uber-scrutiny to be useful in some way for our social wellbeing - at least in terms of helping us frame the debate about what we can rationally expect from our colleagues, leaders, and managers nowadays. At the very least, it's time to recognize the rules have changed, and we need to learn to live within them. Moreover, a new standard in ethics codes is emerging alongside some related, often overlooked older standards that together appear to put teeth into the need for a values-based environment in this globalized world.

\section{EMBARRASSMENT TO THE COMPANY}

Exhibit A in the corporate world is Boeing's 2005 Code of Ethics. It seems pretty standard for multi-national corporations at first glance, similar to many in that it encourages all employees to obey the law, not engage in conflicts of interest, protect and not exploit company property, not disclose confidential information, and to conduct themselves with integrity, honesty, and impartiality when dealing with stakeholders so as not to profit personally from their positions within the company.

Yet, there is a curious phrase that upon closer scrutiny may hold a key to the future of ethical scrutiny in our world - "Employees will not engage in conduct or activity that may raise questions as to the company's honesty, impartiality, reputation or otherwise cause embarrassment to the company." The entire sentence apparently was what enabled the Board of Directors to fire CEO Harry Stonecipher in 2005 for his sexual indiscretions with a subordinate, but the concept of being heavily sanctioned for causing mere embarrassment to the company is something new, indeed frightening and at the same time refreshingly appropriate.

As background, Stonecipher was hired in 2003 by Boeing to rescue it from its own moral crisis, one that saw a CFO go to jail over a Pentagon procurement scandal and a week later resulted in the resignation of Phil Condit, the prior CEO. (Condit himself was the subject of a number of unsightly rumors for his own "reputation as a womanizer, often with Boeing employees," and his "appetite for the high life" according to Business Week in 2003, with one of his four marriages to a Boeing secretary and a subsequent relationship with a receptionist yielding a legal settlement after the woman lost her job.) Moreover, a few months after that resignation, Boeing agreed to pay over $\$ 70$ million to resolve a large number of claims of sex discrimination that women endured in its factories and offices around the Puget Sound area for years. Boeing fell on some hard times about this time as Airbus began to surge ahead in aircraft orders and Boeing's military contractor business was being penalized for other shortcomings.

Hoisted on his own petard of hypocritical righteousness, Stonecipher was fired by the Board just fifteen months into the CEO job for an affair with an unnamed, "longtime" employee. Stonecipher upon his hiring to replace Condit had required every Boeing employee to sign a copy of the ethics code every year as part of his goal to restore the besmirched reputation of Boeing, and that apparently made any transgression on his part, particularly this one that had become public, hard for the Board to merely overlook. "He let everyone know that even minor violations would not be tolerated, and when one does that, you have to look at that standard," Boeing Chairman Lew Platt said. The board said the relationship was consensual and had no effect on the conduct of the company's business; nor was there any issue of whether Stonecipher had influenced his paramour's career or salary, according to Platt.

The company's directors determined that Stonecipher's actions were nonetheless inconsistent with Boeing's code of conduct. "The board concluded that the facts reflected poorly on Harry's judgment and would impair his ability to lead the company," said Platt. "The resignation was in no way related to the company's operational performance or financial condition, both of which remain strong. However, the CEO must set the standard for 
unimpeachable professional and personal behavior, and the board determined that this was the right and necessary decision under the circumstances," he added. Platt said the affair alone was not a violation of Boeing's code of conduct, but he refused to be more specific. Yet, amidst the personal hypocrisy surrounding Stonecipher's adulterous activities (Stonecipher was married with adult children), Boeing's stock rose over 50\% during Stonecipher's tenure. And on the day of the announcement of his forced resignation, Boeing's stock was barely affected, falling just 8 cents to $\$ 58.30$.

Critics were out in full force after the decision. In examining the standard of "embarrassment" to the company for termination cause, naysayers hastened to point out the inherent ambiguity of what constitutes sanctionable shame - how can anyone conform his or her behavior to such an amorphous statement? Besides, in examining the ethics codes of the other Fortune 100 American companies, only Target has a similar "embarrassment phraseology - "All team members and their immediate families are required to act in a manner that will avoid loss or embarrassment to the company." (Target's Business Conduct Guide, p. 4) United Technologies' Code of Ethics, page 10, and Honeywell's Code of Business Conduct, page 7, both contain language stating the companies will not interfere in personal life conduct unless it "impairs... work performance" or "affects the reputation" of the company. Coca Cola's Code of Business Conduct, page 8, warns its employees to "never engage in behavior that harms the reputation of the Company. If you wouldn't want to tell your parents or your children about your action - or wouldn't want to read about it in a newspaper-don't do it."

Therefore it could be easy to conclude Boeing is the outlier, a calculated over-reaction to transform a culture of permissiveness while sending a public message to their major client, the military, that Boeing, too, is serious about the ramifications of possible compromised mission-focus at the top. After all, the military has its own code of ethics, employing, in part, Article 134, known as the "General Article" that can criminalize adultery or fraternization of the sort between officers and enlisted persons, when it could "bring discredit upon the armed forces," be "prejudicial to good order and discipline," or have a "detrimental effect on unit or organization morale, teamwork, and efficiency" all of which sound similar to a general embarrassment clause. Perhaps one could conclude that this is nothing more than Boeing's attempt to provide supplier-customer consonance in terms of moral rectitude during a time of high public scrutiny, along with a 'we mean it' statement about any future prospects of sexual harassment. Yet, despite the temptation to call this an aberration involving an unusual set of circumstances amidst a bad couple of years at a major public corporation with the military as a de facto partner, the precedent of this ethics proviso has been set and survives.

Maybe upon closer reflection, though, Boeing's embarrassment clause is quite cutting edge; Boeing indeed got this right for all the right reasons, despite the Board's inability to articulate it; and ultimately, everyone else in the corporate world, whether they have military contracts or not, will eventually have to follow in some form. After all, business leaders need to understand that a flagrant disregard for moral judgment harms not only their own personal and professional reputations, but in turn, diminishes the reputations of the companies they lead - and it is increasingly becoming unacceptable to the stakeholders.

It's interesting to note that once Boeing weathered the criticism of this firing, its corporate performance since then has been remarkable. Its share price was over $\$ 85$, an increase of over $60 \%$, just within fifteen months of the Stonecipher firing. It is winning significantly more contracts for airplane purchases over its rival, Airbus, internationally, and the corporate culture seems to have been transformed. Thus, the argument of critics at the time that the market made nothing of it and the outcome left nobody, particularly the shareholders and customers, better off seems to be too ingenuously presumptuous in retrospect. (A recent study by Santa Clara University professor Meir Statman on the returns of Fortune Magazine's annual list of "Most Admired Companies" from 1983-2006 showed that those with lower overall reputations outperformed those of higher-ranked reputations, with annualized returns of $17.8 \%$ vs. $15.4 \%$ respectively. However, both groups beat S\&P's 500 annualized returns of $11.2 \%$ during that period. Before any conclusions about how and whether the market values reputation can be drawn from this study, it should be noted that the average price-to-book ratio of top reputation companies was 2.07 vs. 1.27 of the not-so-admired group, while the high reputation companies had much larger market caps, as well. It may be, as the author suggests, that the market does indeed value good reputations in companies, but may over-value them in comparison to those at the lower end of the scale, thus reducing the average annualized returns, while bidding up the price of their stock.) 
As an aside, many veteran Boeing employees are quick to observe that McDonnell Douglas employees, like Stonecipher, came from a culture that pushed the limits of acceptable behaviors on many fronts, and that the merger of these two rivals in 1997 had to yield some traumatic shakeout in an organizational sense. Admittedly, this could all be overturned in heartbeat with a new untoward revelation or scandal, but the code of ethics has stuck and reportedly a number of employees were shown the door for transgressions in violation of the code both before and after Stonecipher's demise. He was a prime example, but apparently not alone, in more ways than one.

This phenomenon of holding leaders to ever-increasing standards of professional, private and public judgment is not limited to the industrialized West, however. Witness the current investigation in China of over 17,000 Communist Party functionaries for abuse of their positions for personal gain, and the specific focus of hundreds of mayoral officials in Shanghai concerning the looting of public pension funds. International observers in Thailand say that the primary downfall of former Prime Minister Thaksin Shinawatra in the bloodless coup that occurred in September was due in large measure to his blatant cronyism, using his position to assist his friends and family while his large corporate holdings benefited as well. Some of this Asian movement to discard leaders engaged in private inurement at the expense of the public taxpayer can be traced back to the Indonesian revolution involving Suharto's fall from power in the late ' 90 's and even as far back as the Filipino revolution against Marcos in the ' 80 's. Circumstances surrounding each of these separate episodes were obviously different, but each was attended by some form of a populist-fed discontent, intent on making an example out of the perceived personal aggrandizement excesses and duplicity of their leaders.

Certainly, national cultural biases and worldviews play a part in determining the public's view of infidelity. A recent book by a former Wall Street Journal reporter, Pamela Druckerman, finds very few reliable, hard published data on adultery and its condemnation societally. However, in reviewing some unpublished data at the London School of Hygiene and Tropical Medicine, she goes on to deduce that Americans are neurotic about adultery, while the French are tolerant of infidelity and rarely confront a spouse for cheating, plus find it reprehensible that Americans even discuss being monogamous publicly. Druckerman concludes that people in rich countries value monogamy and tend not to stray often, but in America, "adultery crises last longer, cost more, and seem to inflict more emotional torture." (By the way, those peoples who say they stray the least are the Swiss and the Australians, according to the study, while sub-Saharan Africans reportedly stray the most.) Nonetheless, with American companies dominating the number of large MNC's globally and the American financial markets and economy holding sway in globalization, the cultural judgments and impacts of infidelity at the top of an American-based corporation could certainly reverberate and have influence beyond American shores.

\section{MORAL TURPITUDE}

More and more local governments and faith-based institutions in the US are drafting codes of conduct for more than just employees, to include board directors and even contractors. And many have included a catch-all phrase, similar in scope, to proscribe behaviors that could be termed "moral turpitude." A quick survey of local government codes from California through Missouri to Maine reveals use of this phrase time and again as grounds for termination. Witness Spokane, Washington's reaction to the homosexual improprieties of former Mayor Jim West, who was voted out of office on a recall campaign once his predatorial actions were exposed by the local newspaper. In response to the lack of an impeachment provision in the city code thus forcing the recall election, a new ethics code was proposed and passed overwhelmingly in a recent ballot vote, which included the ubiquitous "moral turpitude" clause.

Common law viewed "moral turpitude" as an act that was "intrinsically or morally wrong." Today's use of "moral turpitude" as discrediting and prohibitive conduct traces its origins to criminal law and specifically to immigration law. For over 100 years, since an 1891 Congressional Act, "crimes of moral turpitude" have been used to exclude or deport aliens. From 1908 to 1980, the INS deported over 16,000 aliens for immoral behavior, and in 1987 alone over 2500 aliens were excluded on the ground of "crimes involving moral turpitude." Courts faced with interpreting the term often refer to Black's Law Dictionary, which defines "moral turpitude" as: 
[an] act of baseness, vileness, or the depravity in private and social duties which man owes to his fellow man, or to society in general, contrary to the accepted and customary rule of right and duty between man and man... that gravely violates moral sentiment or accepted moral standards of community and is a morally culpable quality held to be present in some criminal offenses as distinguished from others...

The Board of Immigration Appeals has described it as conduct that "shocks the public conscience," while other courts state that it is "anything done contrary to justice, honesty, or good morals or which "grievously offends the moral code of mankind." Some legal commentators and even the US Department of State in its Foreign Affairs Manual for adjudicating visas, have divided "crimes of moral turpitude" into three categories: 1) crimes against property (i.e. robbery, burglary, blackmail, extortion, arson, forgery, embezzlement and false pretenses); 2) crimes against the person, including sex crimes (i.e. adultery, contributing to the delinquency of a minor, incest, kidnapping, lewdness, assault, manslaughter, murder, prostitution, rape, libel, and riot), and 3) crimes of fraud against the government or appropriate authority (i.e. bribery, fraud, perjury, tax evasion, drunkenness, smuggling and customs violations, and vagrancy). The phrase has not been held to be void for vagueness, however, by two US Supreme Court cases, providing deference to those agencies who would be in a better position to define the boundaries of the term over time, despite the threat of arbitrary enforcement.

Moral turpitude has been used for decades to disbar attorneys and is still in place in the ABA Rules of Model Code of Professional Responsibility; it has been a standard to revoke physicians' and accounting licenses and for other professional licensure requirements, including nowadays the bylaws of the Association of Certified Fraud Examiners. The term is used currently by such diverse groups as the Ethics Commission of San Francisco, the City Charters for Auburn, Maine and Neosho, Missouri, and in Codes of Ethics or contracts with non-profits and various for-profits, such as the Colorado Health Foundation, the South Florida Workforce Board of Miami-Dade and Monroe Counties, CSS Industries, Inc., and BMC Software, Inc., to name a few.

In Hollywood, studio executives for scores of years had corporate lawyers write into contracts of their actors and actresses a paragraph called a "morals clause" that invoked cancellation of the contract upon the commission of any act of moral turpitude under federal, state, or local laws, or which might tend to bring the artist into public disrepute.

Thus, moral turpitude can -- as does an "embarrassment" clause with its deliberate ambiguity -- extend to a number of obscene and amoral private behavioral scenarios in all sorts of arenas; in the current socio-cultural climate, it may be similar to how Supreme Court Justice Potter Stewart didn't define 'pornography' - "I know it when I see it." And that may not be so bad. While "moral turpitude" can hardly be characterized as a precise term in any way, its flexibility was and is apparently by design, to accommodate changing norms of behavior, according to legal experts. (Harms, Brian, "Redefining 'Crimes of Moral Turpitude': A Proposal to Congress", 15 Georgetown Immigration Law Journal 259, Winter 2001) The judicial or arbitral application of the phrase was intended to be applied to specific facts, involving some exercise of discretion, even to adapt to new moral standards. And that is what could be the beauty in its application in corporate globalization.

Depending upon the nature and severity of the offense, the level of the employee/manager/executive, the extent of the external and internal circumstances faced by the corporation and its impact on stakeholders, and even the degree of repentance reflected by the offender, boards may exhibit a wide range of choices in terms of punishment -and in the process develop their own set of precedents and lines drawn in the sand. Yes, there will be lawsuits for possible arbitrariness in its application by careless boards and executives, but that will occur in any line of ethical judgment.

While an "embarrassment clause" might actually be broader than even acts of "moral turpitude" based on the historical baggage of moral turpitude, the nature of both is that they revolve around the need for a determination of combining personal behavior with the needs of developing or enforcing an institution's values. We judge leaders today not by just their own behavior or the results achieved, but by the organizational culture they shape and the behaviors modeled or exhibited by others under their influence, globally and locally. And, as one commentator said, it's time for us to recognize that corporate, governmental, non-profit and NGO leaders are responsible for "values that 
go beyond the walls of a single organization." (Kanter, Rosabeth, "The Matter With the Mainstream", US News \& World Report, October 30, 2005, p. 31)

\section{INSUFFICIENCY OF LEGAL ANALYSIS}

Issues of agency representation in the context of how and what one did in private used to be easy to comprehend - what you did on your own time was your own business, period. Common law concepts of respondeat superior, apparent authority, and breaches of fiduciary duties made for great legal debates, but the harsh reality is that many business and government officials are coming to the conclusion that the public cannot nor will it distinguish between public work and private life duties - in short, no matter what, leaders and managers are on the clock $24 / 7 / 365$, at least as far as the globally-wired community is concerned. The old rules of privacy for public and corporate officials are being rewritten, and the definitions of what constitutes public accountability and transparency encompass more than we care to admit - truth be told, it covers not just government officials, but most everyone in all sorts of positions of power in publicly-held and privately-held companies, be they for-profit or non-profit.

\section{NEW STANDARD REDUX}

The new ethics proviso of embarrassment to the company or moral turpitude in the "glocalized" corporate arena boils down to avoiding actions that would substantially damage the reputation, image, and trust (brand) of the company - or what would cause a loss of trust or "face" by the public. How is that measured? Easily in this day and age, with polls, attitudinal surveys and ultimately votes and money spent. Consumer surveys and polling data now are being used to quickly assess the diminishment of value or attitudes toward an individual or entity - how and what facts that diminishment is based upon are the major issues that we and corporate boards will struggle with as a society in this instant-fix, news-breaking world in which we live.

Perhaps, what we will conclude after seeing so many of our public and corporate officials being held to this Boeing-like standard is that all people have clay feet. None of us are perfect, but transparency and accountability won't go away, nor should they. Those in positions of power and influence (whether they be in government, publiclytraded companies, or representatives of non-profit or NGO entities) whose behaviors could have a non-trivial impact on the communities in which we live must now constantly ask themselves the following questions: 1) At what point am I or my family or friends benefiting as a direct result of my undue influence by virtue of my position of power; 2) To what extent might my actions if published on the front page of the newspaper or television or online be construed as the appearance of impropriety to the extent it could harm the public's faith or trust in the entity I represent, whether I'm "on the job" or not; and finally, 3) Are any of my private life actions capable of being construed as hypocritical when compared to my public life service and pronouncements?

Socrates reportedly said, "An unexamined life is not worth living." In this day and age, everything is examined ad nauseum now in real time and for decades. In a world of no secrets, with "No Place to Run To, No Place to Hide," maybe we'll learn that the truth, especially in its most extreme and exposed form, matters. And perhaps we'll eventually learn to provide grace where it is due, sanctions when they are due, and to know the difference, thereby coming to a better understanding of the human condition. God help us, indeed. - Copyright Kyle B. Usrey, April 2007

\section{BOEING CODE OF CONDUCT - 2005}

The Boeing Code of Conduct outlines expected behaviors for all Boeing employees. Boeing will conduct its business fairly, impartially, in an ethical and proper manner, and in full compliance with all applicable laws and regulations. In conducting its business, integrity must underlie all company relationships, including those with customers, suppliers, communities and among employees. The highest standards of ethical business conduct are required of Boeing employees in the performance of their company responsibilities. Employees will not engage in conduct or activity that may raise questions as to the company's honesty, impartiality, reputation or otherwise cause embarrassment to the company. 
Employees will ensure that:

- They do not engage in any activity that might create a conflict of interest for the company or for themselves individually.

- They do not take advantage of their Boeing position to seek personal gain through the inappropriate use of Boeing or non-public information or abuse of their position. This includes not engaging in insider trading.

- They will follow all restrictions on use and disclosure of information. This includes following all requirements for protecting Boeing information and ensuring that non- Boeing proprietary information is used and disclosed only as authorized by the owner of the information or as otherwise permitted by law.

- They observe that fair dealing is the foundation for all of our transactions and interactions.

- They will protect all company, customer and supplier assets and use them only for appropriate company approved activities.

- Without exception, they will comply with all applicable laws, rules and regulations.

- They will promptly report any illegal or unethical conduct to management or other appropriate authorities (i.e., Ethics, Law, Security, EEO).

Every employee has the responsibility to ask questions, seek guidance and report suspected violations of this Code of Conduct. Retaliation against employees who come forward to raise genuine concerns will not be tolerated.

\section{BIBLIOGRAPHY}

1. 485.

2.

3.

4.

5.

6. $\quad$ Brush, Silla. A Vote of No Confidence. U. S. News \& World Report, October 30, 2006.

7. Davis. Handbook of Criminal Evidence. 2000.

8. Druckerman, Pamela. Lust in Translation: The Rules of Infidelity from Tokyo to Tennessee. Penguin Press, 2007.

9. Harms, Brian C. Redefining 'Crimes of Moral Turpitude': A Proposal to Congress. Georgetown Immigration Law Journal, 2001.

10. Jennings, Kate. The Hypocrisy of Wall Street Culture. New York Times Company, July 14, 2002.

11. Kanter, Rosabeth Moss. The Matter With the Mainstream. U.S. News \& World Report, October 30, 2006.

12. Lewis, Al. Why MBA Students Are Such Cheaters. The Week, October 13, 2006.

13. Pearlstein, Steven. Ethics Pedestal Assures Some Hard Falls. The Washington Post Company, 2002-2006.

14. Schramm, Jennifer. Perceptions on Ethics. Society for Human Resource Management, 2004. Gale Group, 2005.

15. Statman, Meir. Sometimes the Worst Are First. Fortune, May 5, 2007.

16. Tong, Vinnee. LRN Survey Finds Unethical Corporate Managers Contribute to Lower Worker Productivity. The Associated Press, 2006.

17. Wallace, James. Boeing leader Ousted. Seattle Post Intelligencer, March 8, 2005.

18. Wayne, Leslie. Boeing Chief Is Ousted After Admitting Affair. New York Times, March 8, 2005.

19. Wolters, Roger S. Moral Turpitude in the Industrial Environment: A Real Dilemma. Labor Law Journal; Apr76, Vol. 27, Issue 4, p. 245-254. 
International Business \& Economics Research Journal - September 2007

Volume 6, Number 9

\section{NOTES}

